\title{
Population Dynamics Between Fusarium pseudograminearum and Bipolaris sorokiniana in Wheat Stems Using Real-Time qPCR
}

Ernesto A. Moya-Elizondo, Instituto de Producción y Sanidad Vegetal, Facultad de Ciencias Agrarias Universidad Austral de Chile, Valdivia, Chile; and Barry J. Jacobsen, Andrew C. Hogg, and Alan T. Dyer, Department of Plant Sciences and Plant Pathology, Montana State University, Bozeman 59717-3150

\begin{abstract}
Moya-Elizondo, E. A., Jacobsen, B. J., Hogg, A. C., and Dyer, A. T. 2011. Population dynamics between Fusarium pseudograminearum and Bipolaris sorokiniana in wheat stems using real-time qPCR. Plant Dis. 95:1089-1098.

Fusarium pseudograminearum and Bipolaris sorokiniana are causal agents of Fusarium crown rot and common root rot, respectively, of wheat and cause significant losses worldwide. Understanding the population dynamics between these two pathogens at late stages of wheat development is needed. The effect of $F$. pseudograminearum and $B$. sorokiniana inocula applied singly or in mixtures at seeding to spring wheat 'Hank' was measured using seedling stand, grain yield, and pathogen populations in the first internode at heading, milk, and harvest stage of wheat development using real-time quantitative polymerase chain reaction. High and low rates of $F$. pseudograminearum inoculum reduced $B$. sorokiniana populations in field trials but $B$.

sorokiniana inoculations did not affect $F$. pseudograminearum populations. Populations of both pathogens increased from heading until harvest, with $F$. pseudograminearum colonizing lower internodes earlier than B. sorokiniana. Neither pathogen prevented infection by the other in the first internode of wheat stems. Inoculations increased incidence of infection and co-infection relative to natural settings observed for both pathogens. At the seedling stage, both fungi, individually or combined, reduced the seedling stands when compared with a noninoculated control for the three location-years. Grain yield and F. pseudograminearum populations were inversely correlated, while B. sorokiniana populations were not correlated with yield.
\end{abstract}

Fusarium crown rot (FCR) and common root rot (CRR) of wheat and other cereals are endemic disease problems that cause significant losses in the Northern Great Plains of North America and other semiarid regions of the world $(2,3,35,41,42,44,48,50)$. In Montana and the Pacific Northwest, FCR of small grains is primarily caused by Fusarium culmorum (W. G. Sm.) Sacc. and F. pseudograminearum (O'Donnell \& T. Aoki; group I) (= Gibberella coronicola) $(28,30,31,42)$. In other regions, $F$. graminearum, $F$. avenaceum (Fr.) Sacc., F. acuminatum Ellis \& Everh., F. equiseti (Corda) Sacc., and Microdochium nivale (Fr.) Samuels \& I. C. Hallett $(=F$. nivale $(\mathrm{Fr}$.) Sorauer) have been associated with crown rot of cereals $(2,10,14,33,43,48)$. Bipolaris sorokiniana (Sacc.) Shoemaker (= Cochliobolus sativus (S. Ito \& Kurib.) Drechsler ex Dastur) is the causal agent of CRR and, with FCR, is part of a complex causing dryland seedling, foot, crown, and root rot in cereals crops across the globe $(7,9,10,13,14,20,22,31,43,44,50)$. Fusarium spp. noted above and $B$. sorokiniana affect wheat and other cereals at every stage of development from seedling through grain fill (20,31).

Among the Fusarium spp. causing crown rot in Montana, F. culmorum causes the greatest losses to seedling blight while $F$. pseudograminearum and $F$. graminearum cause more severe late season disease (8). The adoption of conservation tillage practices in wheatfallow production systems has led to an increase of $F$. pseudograminearum populations in recent years $(31,38)$. F. pseudograminearum is strictly a residue-born pathogen that depends on infested late-season tillers for survival between cropping years $(32,39)$. It has been hypothesized that this places strong selection pressure on the pathogen to capture durable plant residues in order to survive the prolonged non-cropping period (crop/fallow system) of Montana (8). In general, B. sorokiniana is favored by conventional

Corresponding author: A. T. Dyer, E-mail: adyer@montana.edu

Accepted for publication 2 April 2011.

doi:10.1094/PDIS-11-10-0794

(C) 2011 The American Phytopathological Society tillage in barley (13) and wheat production systems $(7,12,26,34,47)$. However, in one study, researchers found higher infection rates where stubble was retained versus where it was removed (51).

Recent surveys in Montana and the Canadian Prairies have shown a negative correlation between populations of FCR and CRR pathogens $(10,28)$. Given the widespread geographical range and economic importance of FCR and CRR in cereal cropping systems, it is important to understand the potential for antagonism between the causal pathogens because this may have practical control implications. Dual-inoculation studies between FCR and CRR pathogens have been conducted since the 1930s (21) to address potential interaction between these pathogens. Ledingham's work (21) determined an antagonistic effect on seedling emergence of wheat plants simultaneously inoculated with $F$. culmorum and $B$. sorokiniana. Tinline (46) reported that colonization of the internode by $B$. sorokiniana does not prevent subsequent invasion by fusaria; however, prepossession of the internode by fusaria greatly reduces subsequent infection by $B$. sorokiniana in studies of single or combination inoculation of wheat with B. sorokiniana, F. culmorum, and $F$. acuminatum. Scardaci and Webster (36) identified antagonism between $F$. graminearum and $B$. sorokiniana when they were co-inoculated in barley, resulting in lower levels of seedling blight and root rot. These authors also determined that, when the pathogens were inoculated in sequence, one 21 days before the other, the pathogen inoculated first was reisolated most frequently, indicating the importance of prior colonization and possession of substrate. Fernandez et al. (11) showed that $F$. acuminatum inoculation significantly augmented the effect of $B$. sorokiniana infection when wheat seedling plants were inoculated with both fungi. Although these studies have demonstrated potential antagonism between these pathogens, it is important to understand that they were carried out using autoclaved soil to avoid masking the interaction between the cereal root rot pathogens by other microflora. This does not simulate the environment confronted by these two pathogens in a field situation. In the one study conducted under field conditions, co-inoculations with $F$. culmorum and B. sorokiniana did not affect wheat emergence or yield (21) but no data were collected on relative population dynamics or their impact on late-season crown and root rot was not reported. 
Assessing pathogen population dynamics in wheat tissues has historically been done using isolation and culturing of targeted pathogen species. This method is labor intensive and complicated by many factors such as competition and antagonism from other organisms in plant tissue, needed expertise in identifying species, and media selectivity that may favor isolation of certain fungi over others (16). Given these numerous limitations, Pettitt et al. (33) suggested that pathogen-pathogen interactions within wheat stems would be best assessed by using real-time quantitative polymerase chain reactions (qPCRs). These qPCR methods have already been proven invaluable in other systems where assessments of competition and interactions among ectomycorrhizal fungi and among alfalfa root pathogens have been successfully conducted $(17,49)$. Recently, a number of qPCR assays have been developed to quantify FCR and CRR pathogen populations but have yet to be applied to assess interactions among the species $(15,16,28,45)$. Because both FCR and CRR incidence and severity are increasing under conservation tillage systems, and because negative associations between the causal pathogens have been documented, it is important to assess the potential interaction between these pathogens, particularly at later stages of wheat development under field conditions. To address this need, this study examined the disease and the pathogen community dynamics between aggressive pathogenic isolates of $F$. pseudograminearum and $B$. sorokiniana within inoculated wheat plants at seedling, heading, milk, and harvest stages of wheat development under field conditions using qPCR. These results were then compared with observations made on individual tillers collected at harvest from inoculated spring wheat plots and from naturally infested commercial spring and winter wheat fields.

\section{Materials and Methods}

Pathogen isolates and wheat cultivar. Field trials were conducted to assess the population interactions between $F$. pseudograminearum isolate 2228 (Fpg2228) and B. sorokiniana isolate 2344 (Bs2344) in the hard red spring wheat (Triticum aestivum L.) 'Hank' (WestBred, Bozeman, MT). Isolate Fpg2228, collected in Loma, MT (Liberty County), was chosen for the Fusarium inoculations because it is an aggressive isolate that reduced yield on wheat (8). Isolate Bs2344, collected in Carter, MT (Chouteau County), was chosen for $B$. sorokiniana inoculations for the same reason as described for Fpg2228 (A. T. Dyer, unpublished data). For both fungi, oat kernel inoculum was produced as described by Mathre and Johnston (27).

Field trials with $F$. pseudograminearum and $B$. sorokiniana. During the summer of 2008 and 2009, three experiments were conducted to assess the population dynamics between $F$. pseudograminearum and B. sorokiniana within spring wheat during seedling (Feekes growth stage 1), heading (Feekes growth stages 10.1 to 10.5), milk (Feekes growth stage 10.54), and harvest (Feekes growth stage 11) stages. Trials were conducted at the Montana State University (MSU) Arthur H. Post Research Farm (Bozeman, MT) in 2008 and 2009, and at the MSU Central Agricultural Research Center (Moccasin, MT) in 2008. Soil at the Bozeman and Moccasin sites are Amsterdam silt loam and Judith clay loam, respectively.

The experimental unit was a plot eight rows wide with $30-\mathrm{cm}$ centers seeded at 200 seeds per 3-m row. Plots were sown on 5 May 2008 and 18 May 2009 in Bozeman and 28 April 2008 in Moccasin. Plots were inoculated in-furrow at planting with Fpg2228 and Bs2344 whole-oat-kernel inoculum using three inoculation rates forming a three-by-three factorial design with six replications for a total of 54 plots. In-furrow inoculation rates were $0 \mathrm{~g}, 1 \mathrm{~g}$ (low), and $3 \mathrm{~g}$ (high) of colonized oat-kernel inoculum per meter of row for both fungi. Field sites were top dress fertilized before seeding with nitrogen at rates of $67.2 \mathrm{~kg} / \mathrm{ha}$ in Moccasin and $51.6 \mathrm{~kg} / \mathrm{ha}$ in Bozeman during 2008, and $78.6 \mathrm{~kg} / \mathrm{ha}$ in Bozeman in 2009. Weeds were controlled at both locations and years by hand hoeing.

Plant emergence was assessed at the two-leaf growth stage (Feekes growth stage 1) between 22 to 25 days post planting.
Emerged seedlings were counted for rows 2, 4, and 6 on 27 May 2008 and 2 June 2009 in Bozeman and 20 May 2008 in Moccasin. Thirty tillers were randomly chosen from each plot at the heading stage (Feekes growth stages 10.1 to 10.5), milk stage (Feekes growth stage 10.54), and harvest stage (Feekes growth stage 11) for DNA extraction and qPCR analysis. During heading and milk stage sampling times, stems were collected from the second and seventh rows, while rows three through six were left for yield analysis. Stem collection at the heading stage was done on 11 July 2008 and 16 July 2009 in Bozeman and on 8 July 2008 at Moccasin. Milk stage stem collection was conducted on 18 July 2008 and 6 August 2009 in Bozeman and 21 July 2008 in Moccasin. Stems for harvest stage analyses were collected from the middle four rows of the plots after harvest on 27 August 2008 and 16 September 2009 in Bozeman. In Moccasin, stems were collected on 22 August 2008.

The middle four rows of each plot in Moccasin were harvested with a Wintersteiger plot combine (Wintersteiger USA Inc., Salt Lake City, UT), while the four middle rows of each plot in the Bozeman experiments were harvested with a small-bundle rice binder (Mitsubishi Agricultural Machinery Co., Ltd., Tokyo) and threshed using a Vogel thresher (Bill's Welding, Pullman, WA).

DNA isolation. To isolate pathogen DNA within wheat tillers, the leaf tissue was removed from the 30 collected tillers and 3-mm stems sections were cut from the base of the first internode of each tiller. These tissue samples were then processed following protocols previously described by Hogg et al. (15) using FastDNA kits (QBiogene Inc., Irvine, CA). The resulting DNA samples were diluted 1:10 with molecular-grade water for qPCR analysis.

Quantification of pathogens from first internode infections. Real-time qPCR quantification of $B$. sorokiniana and $F$. pseudograminearum populations within plant tissues used probes duallabeled with 6-carboxyfluorescein fluorescent reporter dye and 6carboxyltetramethylrhodamine fluorescence quencher. The primerprobe combination used to quantify $F$. pseudograminearum populations was previously described $(15,45)$. For $B$. sorokiniana, primers and probe were designed using reported sequences of glyceraldeyde-3-phosphate dehydrogenase-like $(g p d)$ gene sequence for isolate ND93-1, GenBank accession EF513209.1, as described by Moya et al. (28). All qPCR assays were performed using the Rotor-Gene Q (QBiogene Inc.) and a two-step protocol with the following thermocycling parameters: $95^{\circ} \mathrm{C}$ for $10 \mathrm{~min}$, followed by 40 cycles of $95^{\circ} \mathrm{C}$ for $15 \mathrm{~s}$ and $60^{\circ} \mathrm{C}$ for $60 \mathrm{~s}$. The 25$\mu \mathrm{l}$ reaction for qPCR contained $12.5 \mu \mathrm{l}$ of Universal TaqMan Master Mix (Applied Biosystems, Carlsbad, CA), $2.5 \mu \mathrm{l}$ of $2 \mu \mathrm{M}$ TaqMan probe, $2.25 \mu \mathrm{l}$ of a 1:1 mixture of $20 \mu \mathrm{M}$ forward and reverse primers (Integrated DNA Technologies, Inc. Coralville, IA), $2.75 \mu \mathrm{l}$ of molecular-grade water, and $5 \mu \mathrm{l}$ of DNA sample. Each run included four 10 -fold-dilution standards, ranging from 6.6 million to 6,600 copies. For $F$. pseudograminearum and $B$. sorokiniana, the DNA standards used for absolute quantification during qPCR were cloned fragments of the tri5 and gpd genes taken from $F$. culmorum isolate 2223 (15) and B. sorokiniana isolate 2234, respectively. The process of quantification followed the protocol as described by Moya et al. (28). As an internal control, all DNA samples were spiked with 335 pg of plasmid DNA containing the $\beta$-actin gene from Meloidogyne javanica (29). qPCR reactions for this internal control were run for all DNA samples to determine any inhibition of qPCR reactions. No inhibition of qPCR reactions was detected using this internal control. In this article, DNA copy numbers of the tri5 gene was considered as the quantified population of Fusarium spp. of the FCR complex (F. culmorum, $F$. pseudograminearum, and $F$. graminearum), while the amount of DNA copy numbers of the gpd gene was considered the quantified population of $B$. sorokiniana.

Evaluation of Fusarium spp. and $B$. sorokiniana infections in the first internode of individual wheat tillers. DNA quantification of Fusarium spp. and B. sorokiniana populations in the first internode of individual tillers was conducted to assess the dynamics between the two fungal species in experimentally inoculated 
wheat tillers and tillers collected from naturally infected fields. In 2008, 20 symptomatic tillers were obtained from the spring wheat plots inoculated with FCR and CRR pathogens at Bozeman, MT, a naturally infested spring wheat field in Shonkin, MT, and a winter wheat field in Carter, MT naturally infected with both diseases. During 2009, 20 tillers showing symptoms of the disease were obtained from the inoculated spring wheat plots in Bozeman, MT, naturally infested spring wheat in Cut Bank, MT, and naturally infested winter wheat in Malta, MT. Tillers from the spring wheat field trials were chosen after harvest from the plots inoculated with the high rate of both pathogens ( $3 \mathrm{~g}$ of inoculum per meter of row of each fungus). Tillers from the naturally infested commercial wheat fields were obtained a week before harvest. From each stem, a 3-mm section from the base of the first internode was cut, and the DNA was extracted and then quantified for populations of Fusarium spp. and $B$. sorokiniana following the method described above.

Statistical analyses. Multifactor analyses of variance (ANOVAs) considering locations (Moccasin 2008 and Bozeman 2008 and 2009) and inoculation treatments $(3 \times 3$ possible inoculum combinations of Fpg2228 and Bs2234) and interaction between these two factors were conducted for plant emergence, DNA copy numbers of each assessed gene quantified for each date of assessment (heading, milk, and harvest stage), and grain yield. If the factor location was significant $(P<0.05)$ for a variable response, this variable was analyzed separately through a randomized complete block design analysis for each field trial. Multifactor ANOVAs and randomized complete block design analysis were performed by the procedure PROC GLM of the Statistical Analysis System (version 9.2; SAS Institute Inc., Cary, NC) and Fisher's protected least significant difference (LSD) was used to compare means $(P<0.05)$. Prior to analysis, DNA copy numbers quantified through qPCR were $\log (x+1)$ transformed and their variances were analyzed for homogeneity (Levene test, $P>0.05$ ). After the multifactor ANOVAs were conducted, an analysis of covariance was performed on DNA copy number quantified through qPCR in each wheat growth stage by using PROC MIXED with the REPEATED statement for repeated measures (SAS Institute, Inc.), where several covariance matrices were evaluated and the independent structure of covariance between each date of assessment was chosen because it had the lowest Akaike information criterion (AIC) score with the fewest numbers of covariance parameters. This implied that DNA copy numbers quantified at each different stage were independent from one time of assessment to the next. This situation allowed using an univariate analysis split plot in time to assess competition between both pathogen populations in wheat tillers, where the independent variables were different inoculum concentrations of each fungus (none, low, and high), fungal population (Fusarium populations and B. sorokiniana population), and date of assessment (heading, milk stage, and harvest). A univariate analysis split plot in time for the randomized complete block design was performed by the procedure PROC GLM and an LSD test was used to compare means $(P<0.05)$. Relationships between grain yield and level of infection in each disease assessment date (seedling counts, heading, milk stage, and harvest) were evaluated through correlation and regression analyses by using PROC COR and PROC REG (SAS Institute, Inc.), respectively.

Evaluation of the Fusarium spp. and B. sorokiniana populations in individual wheat tillers was conducted on the populations obtained from the 40 tillers collected from naturally infected wheat fields and co-inoculated plot fields during the 2 years of research. Populations of each pathogen observed in wheat tillers during each year were grouped to meet requirements of the statistical test. Number of tillers infected by FCR and CRR pathogens, co-infected tillers, and tillers not infected by the pathogens in each group was determined. Comparisons of observed and expected proportions of each described category of infection among fields were conducted through $\chi^{2}$ tests of homogeneity $(P<0.05)$ and expected proportion of each category within each field was conducted through a $\chi^{2}$ goodness-of-fit test $(P<0.05)$. Wilcoxon signed rank tests with continuity correction were used to compare populations of both pathogens as quantified by qPCR combined across the 2 years for the tillers collected from naturally infected wheat fields and coinoculated plots. The package "Rcmdr" of the R software (www. r-project.org) was used to conduct these nonparametric analyses.

Dependency between Fusarium spp. and B. sorokiniana populations quantified by qPCR at harvest for plots from each location and for the individual tillers collected from the inoculated and naturally infected fields was determined through correlation analyses using PROC COR (SAS Institute Inc.). Spearman rank correlations were considered to avoid distribution effects of analyzed variables.

\section{Results}

Seedling counts were significantly affected by the inoculations of both fungi at the three trial locations (Table $1 ; P<0.001$ ), and a significant interaction between inoculation treatment combinations and location was observed $(P<0.001)$. Across locations, F. pseudograminearum, B. sorokiniana, and combined $F$. pseudograminearum and $B$. sorokiniana inoculations reduced seedling counts by 19,12 , and $27 \%$, respectively. In general, use of inoculum of both Fpg2228 and Bs2344 alone or combined reduced seedling counts for Moccasin by $31 \%$, for Bozeman 2008 by $15 \%$, and for Bozeman 2009 by $20 \%$ when compared with the noninoculated plots. Locations showed different numbers of emerged seedling among trials $(P<0.001)$, with the field trial at Bozeman 2008 showing 17 and $36 \%$ more emerged seedlings than at the Bozeman 2009 and Moccasin 2008 field trials, respectively. At the Bozeman 2008 and Moccasin trials, the treatment inoculated with high rates of both pathogens had the greatest reduction in seedling counts ( 25 and $57 \%$, respectively) but this treatment was not significantly different from the combination of low rates of Fpg2228 and high rates of Bs2344 in the Bozeman 2008 trial. In the Bozeman 2009 field trial, the treatments with high rates of Fpg2228 alone or mixed with high or low rates of Bs2344 caused the greatest reductions in seedling counts $(33,30$, and $27 \%$ reduction, respectively). All field trials showed that treatments inoculated with high rates of Fpg2228 and Bs2344 alone or combined with other rates of both pathogens' inoculum were significantly different than the noninoculated control $(P<0.001)$.

Table 1. Number of emerged wheat seedlings in $3 \mathrm{~m}$ of row at the two-leaf growth stage for different inoculation treatment combinations of Fusarium pseudograminearum isolate 2228 (Fpg) and Bipolaris sorokiniana isolate 2344 (Bs) observed in field trials conducted at Moccasin, MT 2008 and Bozeman, MT 2008 and 2009.

\begin{tabular}{|c|c|c|c|}
\hline \multirow[b]{2}{*}{ Treatments $^{y}$} & \multicolumn{3}{|c|}{ Emerged seedlings in $\mathbf{3} \mathbf{m}$ of row $^{x}$} \\
\hline & Moccasin 2008 & Bozeman 2008 & Bozeman 2009 \\
\hline High Fpg & $81 \mathrm{~d}$ & $150 \mathrm{~cd}$ & $103 \mathrm{e}$ \\
\hline Low Fpg & $114 \mathrm{~b}$ & $161 \mathrm{~b}$ & $135 \mathrm{ab}$ \\
\hline High Fpg-Low Bs & $75 \mathrm{~d}$ & $149 \mathrm{~cd}$ & $112 \mathrm{cde}$ \\
\hline Low Fpg-High Bs & $81 \mathrm{~d}$ & 135 ef & $123 \mathrm{bcd}$ \\
\hline High Fpg-High Bs & $57 \mathrm{e}$ & $131 \mathrm{f}$ & $107 \mathrm{de}$ \\
\hline Low Fpg-Low Bs & $95 \mathrm{c}$ & $156 \mathrm{bc}$ & $130 \mathrm{bc}$ \\
\hline High Bs & $113 \mathrm{~b}$ & $143 \mathrm{de}$ & $133 \mathrm{~b}$ \\
\hline Low Bs & $126 \mathrm{a}$ & $159 \mathrm{~b}$ & $137 \mathrm{ab}$ \\
\hline Noninoculated & $134 \mathrm{a}$ & $174 \mathrm{a}$ & $153 \mathrm{a}$ \\
\hline Overall mean ${ }^{\mathrm{z}}$ & $97 \mathrm{C}$ & $151 \mathrm{~A}$ & $126 \mathrm{~B}$ \\
\hline$P>F$ & $<0.001$ & $<0.001$ & $<0.001$ \\
\hline LSD & 9 & 12 & 8 \\
\hline
\end{tabular}

${ }^{\mathrm{x}}$ Means within a column followed by the same letter were not significantly different according to Fisher's protected least significant difference (LSD, $\alpha=0.05) . P>F$ was the probability associated with the $F$ value.

${ }^{\mathrm{y}}$ Inoculation treatments were $3 \mathrm{~g}$ (high), $1 \mathrm{~g}$ (low), or $0 \mathrm{~g}$ of infested oat seed per meter of row applied in-furrow during seeding.

${ }^{z} P$ values obtained from multifactorial analysis of variance assessed location and the interaction between treatment and location had a probability associated with the $F$ value of $<0.001$. Data indicate overall average for each field trial. Means within a row followed by the same letter were not significantly different according to Fisher's protected least significant difference (LSD, $\alpha=0.05$ ). 
Populations of Fusarium spp. and B. sorokiniana as expressed by DNA copy numbers of the tri5 and gpd genes, respectively, in the three different late stages of plant growth (heading [Feekes growth stages 10.1 to 10.5], milk [Feekes growth stage 10.54], and harvest [Feekes growth stage 11]) were significantly different $(P<$ 0.001). Populations were also significantly different across locations $(P<0.001)$. Therefore, results for each field trial and plant

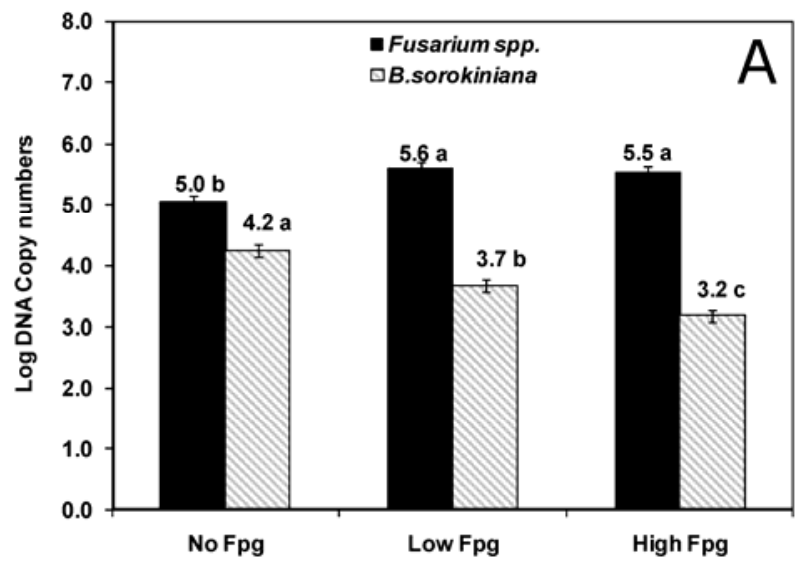

Concentration of inoculum of F. pseudograminearum
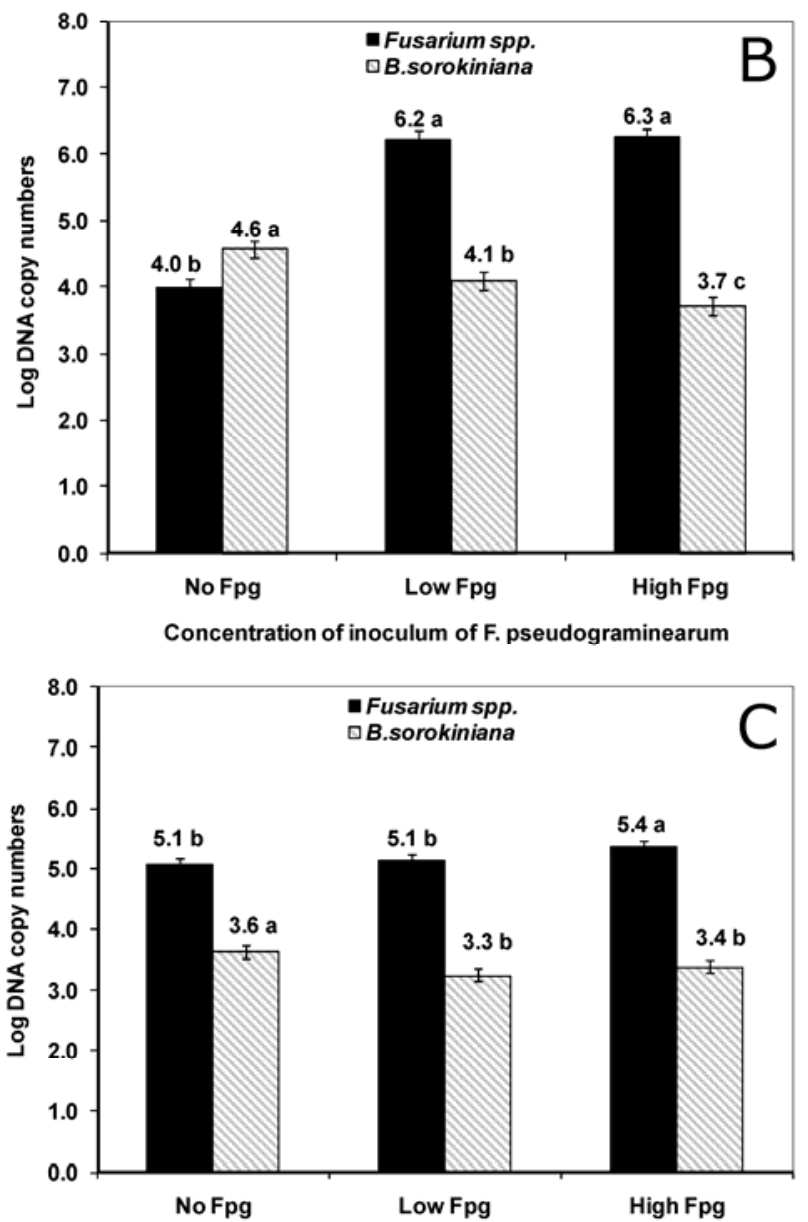

Concentration of inoculum of F. pseudograminearum

Fig. 1. Overall mean copy number for populations of Fusarium spp. and Bipolaris sorokiniana determined across three growth stages through real-time quantitative polymerase chain reaction of the tri5 and gpd genes, respectively, for no-inoculum, low-inoculum, and high-inoculum rates $(0,1$, and $3 \mathrm{~g}$, respectively, of whole-oat inoculum per meter of row) of $F$. pseudograminearum isolate 2228 (Fpg) in field trials conducted in A, Moccasin, MT in 2008 and Bozeman, MT in B, 2008 and C, 2009. Means followed by the same letter on bars of the same color were not significantly different according to Fisher's protected least significant difference ( $\alpha=$ 0.05). Bars on the top of each column represent the standard error. stage were analyzed individually to fully observe the dynamics involved. The analysis of covariance conducted individually on fungal populations for each field trial showed that the structure of covariance between each date of assessment for all field trials had an independent structure (the lowest AIC). This implied that DNA copy numbers of Fusarium spp. and B. sorokiniana quantified at each different stage were independent from one time of assessment

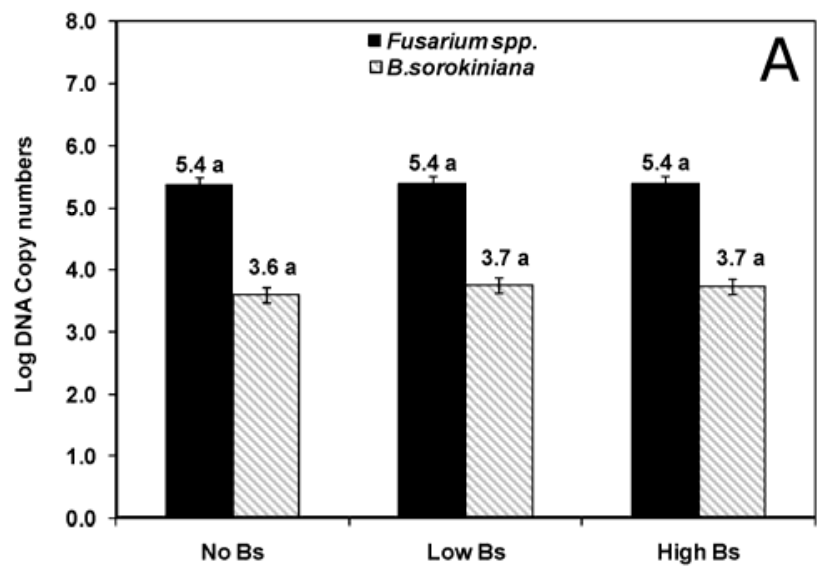

Concentration of inoculum of B. sorokiniana

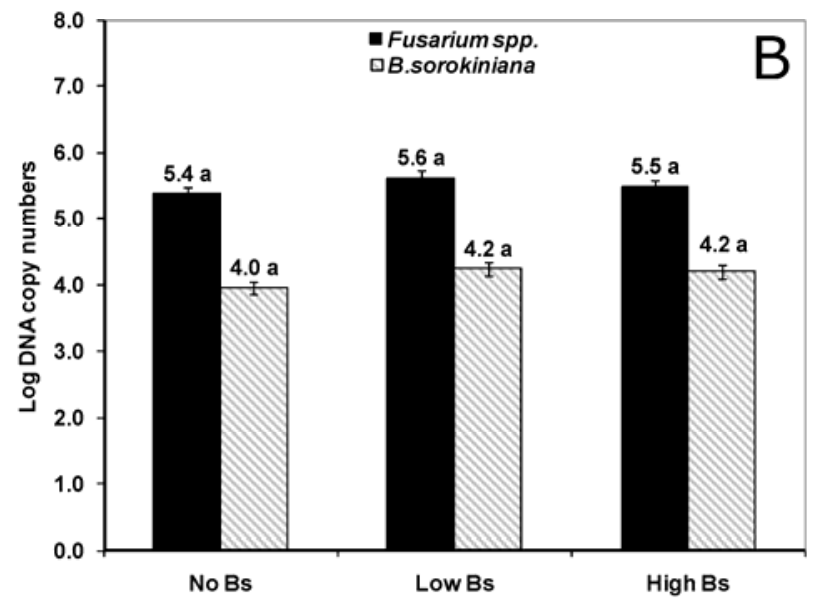

Concentration of inoculum of B. sorokiniana

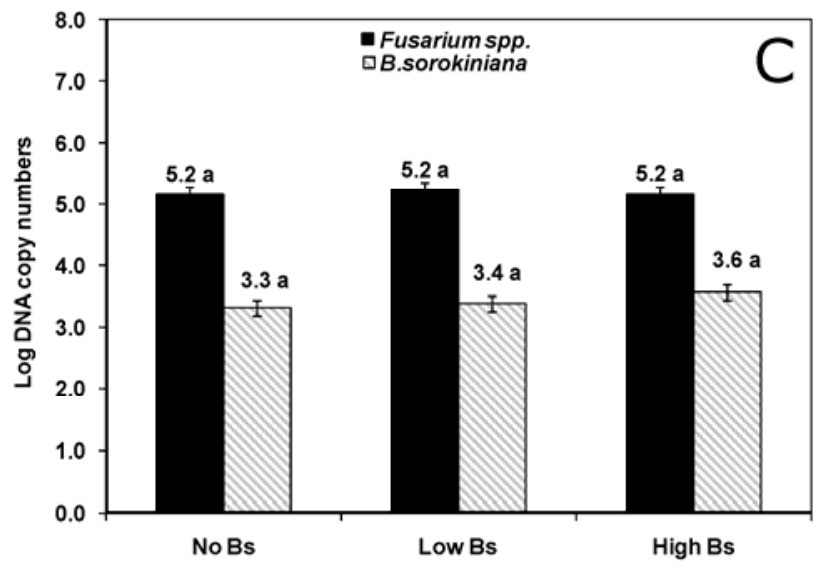

Concentration of inoculum of B. sorokiniana

Fig. 2. Overall mean copy number for populations of Fusarium spp. and Bipolaris sorokiniana determined across three growth stages through real-time quantitative polymerase chain reaction of the tri5 and gpd genes, respectively, for no-inoculum, low-inoculum, and high-inoculum rates $(0,1$, and $3 \mathrm{~g}$, respectively, of whole-oat inoculum per meter of row) of $B$. sorokiniana isolate 2344 (Bs) in field trials conducted in A, Moccasin, MT in 2008 and Bozeman, MT in B, 2008 and C, 2009. Means followed by the same letter on bars of the same color were not significantly different according to Fisher's protected least significant difference $(\alpha=0.05)$. Bars on the top of each column represent the standard error. 
to the next; then, this situation allowed the use of a univariate analysis split plot in time to assess competition between both pathogen populations in wheat tillers (Figs. 1-3). For Moccasin, low and high rates of Fpg2228 inoculum had significantly increased Fusarium spp. populations relative to the noninoculated plots $(P<0.001$; Fig. 1A). Populations of Fusarium spp. were not affected by either rate of Bs2234 inoculum (Fig. 2A). The high rate of Fpg2228 inoculum resulted in a reduced population of $B$. sorokiniana in the first internode of tillers $(P<0.001$; Fig. 1A). The high and low rates of $B$. sorokiniana populations were not different from the noninoculated plots (Fig. 2A). The populations of F. pseudograminearum and $B$. sorokiniana at the Moccasin location were different at the three late stages of wheat development $(P<0.001$; Fig. 2), with the lowest level of Fusarium spp. populations observed during heading (125,346 DNA copies of the tri5 gene), and highest level of this pathogen observed at harvest $(3,168,844$ DNA copies of the tri5 gene) (Fig. 3; Table 2). B. sorokiniana populations were similar during heading $(5,889$ DNA copies of the gpd gene) and milk stage (11,012 DNA copies of the gpd gene) but increased markedly at harvest (192,642 DNA copies of the gpd gene). Also, significant reductions of B. sorokiniana populations were observed in plots single inoculated with Fpg2228 measured at the milk and harvest stages, when means comparison among individual inoculum treatments were analyzed (Table 2 ).

Pathogen populations in the 2008 field trial at Bozeman showed patterns similar to those described for Moccasin. Plots inoculated with Fpg2228 increased the population of the pathogen relative to the noninoculated plots, and this increase was associated with reduction of $B$. sorokiniana populations (Fig. 1B). Populations of $B$. sorokiniana in noninoculated plots were not different from the high and low inoculated rates of Bs2344 $(P=0.104)$ and populations of $F$. pseudograminearum were not affected by the presence of $B$. sorokiniana inoculum (Fig. 2B). Comparison among wheat development stages showed the same level of $F$. pseudograminearum infection between heading and milk stages and significantly higher populations at harvest (Fig. 3; Table 2). B. sorokiniana had low populations during heading stage, as observed in Moccasin, but high populations occurred during milk stage. The effects of Fpg2228 inoculum on $F$. pseudograminearum populations were most dramatic in Bozeman 2008 plots and were much more modest in Moccasin and at Bozeman in 2009. For example, populations of F. pseudograminearum in Bozeman 2008 were, on average, 15 times greater as indicated by DNA copies of tri5 gene than at Moccasin at heading (Table 2). Plots inoculated only with high rates of Fpg2238 showed a clear reduction of B. sorokiniana population during heading and harvest, whereas this phenomenon was observed only at milk and later harvest stages in Moccasin.

Although the population dynamics displayed in Bozeman in 2009 were less dramatic than in the other two trials, they followed similar patterns. F. pseudograminearum inoculations increased infestation with $F$. pseudograminearum populations and those populations reduced the B. sorokiniana populations (Fig. 1C). B. sorokiniana inoculations did not increase its populations significantly and did not increase or reduce $F$. pseudograminearum populations (Fig. 2C). For 2009 in general, F. pseudograminearum and $B$. sorokiniana populations were moderate, never attaining the levels observed in the 2008 trial (Table 2). Populations of F. pseudograminearum were lower at heading and similar at milk stage and harvest stage, whereas $B$. sorokiniana populations increased from heading to harvest (Fig. 3). Significant differences among

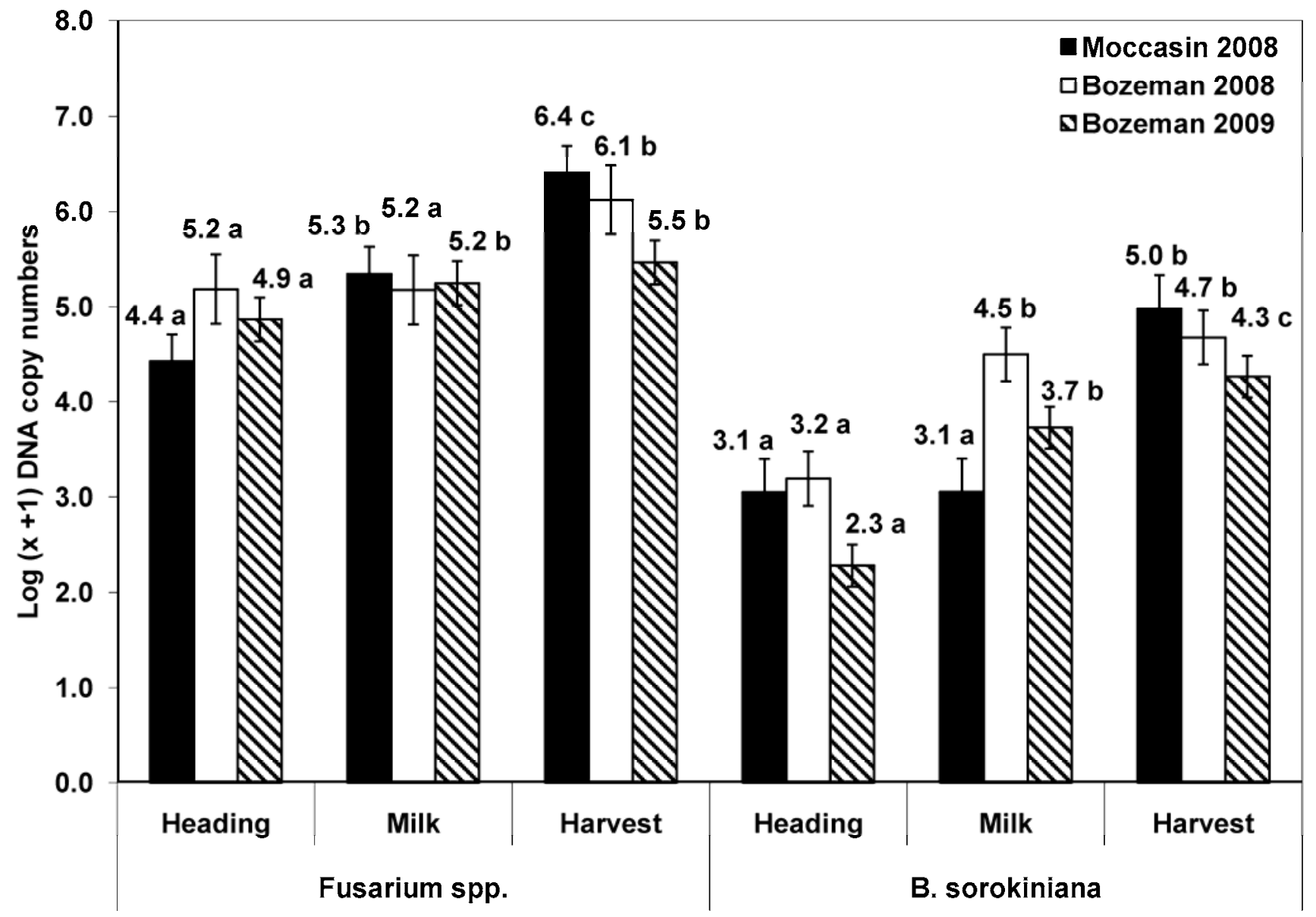

Fig. 3. Mean copy number for populations of Fusarium spp. and Bipolaris sorokiniana determined through real-time quantitative polymerase chain reaction of the tri5 (for Fusarium spp.) and gpd (for B. sorokiniana) genes for three wheat growth stages in Moccasin, MT 2008 and Bozeman, MT 2008 and 2009 field trials inoculated with F. pseudograminearum isolate 2228 and $B$. sorokiniana isolate 2344 . For each species-location value within an inoculum type, means followed by the same letter were not significantly different according to Fisher's protected least significant difference $(\alpha=0.05)$. Bars on the top of each column represent standard error. 
inoculated treatments and the noninoculated control were not observed for the Bozeman 2009 site (Table 2).

F. pseudograminearum colonized wheat tillers earlier than $B$. sorokiniana. Progression of the fungal populations in the first internode in the field trial showed that, at heading, F. pseudograminearum had attained a population that was, on average, $37 \%$ of the final population observed at harvest; meanwhile, B. sorokiniana populations at heading averaged only $5 \%$ of the final population observed at harvest. For $F$. pseudograminearum, populations at heading were 4,65 , and $105 \%$ of the final population observed at harvest in the field trials in Moccasin and Bozeman 2008 and 2009 , whereas B. sorokiniana populations were 3,8 , and $4 \%$, respectively.

Grain yield over the three location-years showed significant differences for the different inoculum treatment combinations used for both fungi $(P<0.001)$. Average grain yields were $1,163 \mathrm{~kg} / \mathrm{ha}$ in Moccasin, $1,843 \mathrm{~kg} / \mathrm{ha}$ in Bozeman 2008, and 3,346 kg/ha in Bozeman 2009. For the Bozeman 2008 field trial, plots inoculated with $F$. pseudograminearum had significantly lower grain yields and those yields were significantly different from both the noninoculated control and the treatments inoculated only with $B$. sorokiniana $(P<0.001)$. Inoculation with high or low rates of $B$. sorokiniana inoculum alone did not reduce grain yield compared with the noninoculated plots. These patterns were not observed in Moccasin and Bozeman 2009 field trials, where grain yields were not significantly different among the inoculum treatments. During 2008, the field plots in Bozeman were affected by an unusual hailstorm during grain fill (early milk stage, Feekes growth stage 10.54).

The relationships between seedling establishment and grain yield was only significant for the Bozeman 2009 site $(r=0.385 ; P$ $=0.004$ ), while fungal population-grain yield relationships were only negatively correlated and significant for $F$. pseudograminearum populations in the Bozeman 2008 and the Moccasin trials $(r=$ $-0.624, P=<0.001$ and $r=-0.384, P=0.004$, respectively). $F$. pseudograminearum populations and grain yield were not significantly correlated for the Bozeman 2009 field trial. B. sorokiniana populations did not affect yield in the three field trials (Moccasin, $P=0.738$; Bozeman 2008, $P=0.382$; and Bozeman 2009, $P=$ 0.544). In 2008, spring weather was cool and wet and was followed by a relatively warm and dry summer in Bozeman compared with the long-term averages registered in that location. Precipitation was $84,68,33$, and $18 \mathrm{~mm}$ and average temperatures were 13 , 20,27 , and $26^{\circ} \mathrm{C}$ for May, June, July, and August, respectively. Weather conditions in Moccasin were cooler compared with Bozeman and were wet at the beginning of the trial and relatively drier

Table 2. Average gene copy number $(\times 1,000)$ for populations of Fusarium spp. and Bipolaris sorokiniana observed within different inoculation treatment combinations of Fusarium pseudograminearum isolate 2228 (Fpg) and B. sorokiniana isolate 2344 (Bs) at three growth stages in field trials conducted at Moccasin, MT 2008 and Bozeman, MT 2008 and 2009 as determined through real-time quantitative polymerase chain reaction ${ }^{\mathrm{x}}$

\begin{tabular}{|c|c|c|c|c|c|c|}
\hline \multirow[b]{2}{*}{ Treatments $^{y}$} & \multicolumn{2}{|c|}{$\begin{array}{c}\text { Heading } \\
\text { (Feekes growth stages 10.1-10.5) }\end{array}$} & \multicolumn{2}{|c|}{$\begin{array}{c}\text { Milk stage } \\
\text { (Feekes growth stage 10.54) }\end{array}$} & \multicolumn{2}{|c|}{$\begin{array}{c}\text { Harvest } \\
\text { (Feekes growth stage 11.0) }\end{array}$} \\
\hline & Fusarium spp. & B. sorokiniana & Fusarium spp. & B. sorokiniana & Fusarium spp. & B. sorokiniana \\
\hline \multicolumn{7}{|l|}{ Moccasin 2008} \\
\hline High Fpg & $181 \mathrm{ab}$ & $5.2 \mathrm{ab}$ & $363 \mathrm{ab}$ & $0.2 \mathrm{c}$ & $3,665 \mathrm{a}$ & $71.2 \mathrm{~d}$ \\
\hline Low Fpg & $201 \mathrm{a}$ & $11.0 \mathrm{ab}$ & $1,210 a b$ & $13.0 \mathrm{ab}$ & $3,590 \mathrm{a}$ & $106.6 \mathrm{~cd}$ \\
\hline High Fpg-Low Bs & $180 \mathrm{ab}$ & $0.6 \mathrm{bc}$ & $1,118 \mathrm{ab}$ & $8.5 \mathrm{ab}$ & $3,611 \mathrm{ab}$ & $71.5 \mathrm{~cd}$ \\
\hline Low Fpg-High Bs & $133 \mathrm{a}$ & $1.7 \mathrm{bc}$ & $1,113 a b$ & $14.7 \mathrm{ab}$ & $2,965 a b$ & $139.1 \mathrm{bc}$ \\
\hline High Fpg-High Bs & $147 \mathrm{ab}$ & $4.5 \mathrm{c}$ & $690 \mathrm{ab}$ & $5.7 \mathrm{~b}$ & $4,217 \mathrm{ab}$ & $72.0 \mathrm{~cd}$ \\
\hline Low Fpg-Low Bs & $97 \mathrm{ab}$ & $2.8 \mathrm{ab}$ & $2,036 \mathrm{a}$ & $1.8 \mathrm{ab}$ & $3,382 \mathrm{ab}$ & $127.4 \mathrm{bc}$ \\
\hline High Bs & $60 \mathrm{ab}$ & $14.5 \mathrm{a}$ & $716 \mathrm{~b}$ & $29.5 \mathrm{ab}$ & $2,708 \mathrm{ab}$ & $412.6 \mathrm{a}$ \\
\hline Low Bs & $96 a b$ & $9.6 \mathrm{ab}$ & $421 \mathrm{ab}$ & $12.2 \mathrm{a}$ & $1,936 \mathrm{~b}$ & $338.5 \mathrm{abc}$ \\
\hline Noninoculated & $33 c$ & $3.1 \mathrm{ab}$ & $304 \mathrm{ab}$ & $13.5 \mathrm{ab}$ & $2,445 a b$ & $395.0 \mathrm{ab}$ \\
\hline Overall mean & 125 & 5.9 & 885 & 11.0 & 3,169 & 192.6 \\
\hline$P>F^{\mathrm{z}}$ & 0.026 & 0.026 & 0.376 & 0.0023 & 0.364 & 0.0011 \\
\hline \multicolumn{7}{|l|}{ Bozeman 2008} \\
\hline High Fpg & $1,685 \mathrm{a}$ & $1.4 \mathrm{~b}$ & $1,848 \mathrm{a}$ & 30.2 & $4,557 \mathrm{a}$ & $18.6 \mathrm{~d}$ \\
\hline Low Fpg & $1,977 \mathrm{a}$ & $3.8 \mathrm{ab}$ & $1,521 \mathrm{a}$ & 30.5 & $2,462 \mathrm{a}$ & $41.6 \mathrm{bc}$ \\
\hline High Fpg-Low Bs & $4,032 \mathrm{a}$ & $2.0 \mathrm{ab}$ & $2,024 \mathrm{a}$ & 73.4 & $3,538 \mathrm{a}$ & $53.0 \mathrm{~cd}$ \\
\hline Low Fpg-High Bs & $1,582 \mathrm{a}$ & $10.2 \mathrm{ab}$ & 828 a & 51.9 & $3,845 \mathrm{a}$ & $62.2 \mathrm{bc}$ \\
\hline High Fpg-High Bs & $2,922 \mathrm{a}$ & $4.5 \mathrm{ab}$ & $2,923 \mathrm{a}$ & 39.5 & $3,891 \mathrm{a}$ & $57.8 \mathrm{bc}$ \\
\hline Low Fpg-Low Bs & $4,412 \mathrm{a}$ & $2.1 \mathrm{a}$ & $2,770 \mathrm{a}$ & 109.6 & $6,669 \mathrm{a}$ & $75.4 \mathrm{bc}$ \\
\hline High Bs & $95 \mathrm{~b}$ & $15.1 \mathrm{a}$ & $17 \mathrm{~b}$ & 64.8 & $309 \mathrm{~b}$ & $172.5 \mathrm{a}$ \\
\hline Low Bs & $31 \mathrm{~b}$ & $12.3 \mathrm{a}$ & $43 \mathrm{~b}$ & 95.6 & $489 \mathrm{~b}$ & $172.5 \mathrm{a}$ \\
\hline Noninoculated & $113 \mathrm{~b}$ & $9.8 \mathrm{a}$ & $31 \mathrm{~b}$ & 97.4 & $220 \mathrm{~b}$ & $110.4 \mathrm{ab}$ \\
\hline Overall mean & 1,872 & 6.8 & 1,334 & 65.9 & 2,887 & 84.9 \\
\hline$P>F^{\mathrm{z}}$ & $<0.0001$ & 0.0261 & $<0.0001$ & 0.2296 & $<0.0001$ & $<0.0001$ \\
\hline \multicolumn{7}{|l|}{ Bozeman 2009} \\
\hline High Fpg & 560 & 0.7 & 205 & 8.4 & 384 & 19.7 \\
\hline Low Fpg & 383 & 0.1 & 286 & 6.3 & 249 & 12.5 \\
\hline High Fpg-Low Bs & 501 & 0.1 & 282 & 6.9 & 431 & 24.6 \\
\hline Low Fpg-High Bs & 355 & 1.9 & 241 & 8.1 & 336 & 21.6 \\
\hline High Fpg-High Bs & 374 & 0.8 & 270 & 6.8 & 414 & 18.1 \\
\hline Low Fpg-Low Bs & 272 & 1.0 & 205 & 7.7 & 331 & 18.0 \\
\hline High Bs & 335 & 1.0 & 144 & 15.1 & 330 & 22.3 \\
\hline Low Bs & 133 & 0.8 & 221 & 6.8 & 320 & 27.4 \\
\hline Noninoculated & 248 & 1.0 & 188 & 8.2 & 203 & 25.0 \\
\hline Overall mean & 351 & 0.8 & 227 & 6.2 & 333 & 21.0 \\
\hline$P>F^{z}$ & 0.1249 & 0.5008 & 0.5832 & 0.6641 & 0.1698 & 0.0988 \\
\hline
\end{tabular}

${ }^{\mathrm{x}}$ Fusarium spp. = populations of F. culmorum, F. pseudograminearum, or F. graminearum that were quantified based on the amount of DNA copy number of the tri5 gene. Populations of $B$. sorokiniana were quantified based on the amount of DNA copy numbers of the gpd gene. For both populations, Mean copy number in table should be multiplied by 1,000 for actual number. Means followed by the same letter in each column were not significantly different according to Fisher's protected least significant difference $(\alpha=0.05)$. Mean separations were performed on copy numbers $\log (x+1)$ transformed for the DNA copy number of the tri 5 and gpd genes.

${ }^{\mathrm{y}}$ Inoculation treatments were $3 \mathrm{~g}$ (high), $1 \mathrm{~g}$ (low), or $0 \mathrm{~g}$ of infested oat seed per meter of row applied in-furrow during seeding.

${ }^{\mathrm{z}} P>F$ was the probability value calculated for copy numbers $\log (x+1)$ transformed for the DNA copy number of the tri 5 and gpd genes. 
during summer months. Precipitation was 110, 75, 11, and $23 \mathrm{~mm}$ and average temperatures were $10,14,19$, and $19^{\circ} \mathrm{C}$ for May, June, July, and August, respectively. In comparison with 2008, weather in Bozeman in 2009 was warmer and dryer in May and was followed by a relatively wetter and cooler summer. Precipitation was 41, 67, 71, and $38 \mathrm{~mm}$ and average temperatures were 17, 18, 24, and $24^{\circ} \mathrm{C}$ for May, June, July, and August, respectively.

Evaluation of Fusarium spp. and B. sorokiniana infections in the first internode of individual wheat tillers. High co-infection of the individual lower internodes by Fusarium spp. and B. sorokiniana was observed in co-inoculated tillers collected in 2008 and 2009 from the experimental sites in Bozeman compared with individual tillers collected from naturally infested fields (Fig. 4). The proportion of lower internodes single infected, co-infected, and noninfected by $F$. pseudograminearum and $B$. sorokiniana as detected by qPCR were similar for the naturally infested spring and winter wheat $\left(\chi^{2}=2.177, P=0.537\right)$. When naturally infested lower internodes of spring or winter wheat were compared with the inoculated spring wheat, the $\chi^{2}$ showed a significant effect of inoculation (spring wheat versus co-inoculated, $\chi^{2}=17,135, P=$ $<0.001$; winter wheat versus co-inoculated, $\chi^{2}=26.876, P=$ $<0.001$ ). In the inoculated plots at Bozeman, F. pseudograminearum was detected in $95 \%$ of the lower internodes examined compared with naturally infested fields, where infections were detected in $60 \%$ of spring wheat and $45 \%$ of winter wheat lower internodes. For B. sorokiniana, the inoculated plots at Bozeman showed that this fungus was identified from $75 \%$ of the lower internodes compared with $53 \%$ of spring wheat and $55 \%$ of winter wheat lower internodes from naturally infested fields. The Wilcoxon signedrank test with continuity correction showed that populations of Fusarium spp. as expressed by DNA copy numbers of the tri5 gene observed in individual lower internodes for tillers collected from the co-inoculated plots in Bozeman $($ mean $=188,210$ DNA copy numbers of the tri 5 gene, standard deviation $[\mathrm{SD}]=235,124$, range $=0$ to 909,154 ) were not different from the FCR populations observed in naturally infested tillers collected from spring wheat fields $(\mathrm{V}=279, P=0.123)$ but different from those collected from winter wheat fields $(\mathrm{V}=85, P<0.001)$, whereas the spring wheat tillers showed higher FCR populations than the winter wheat tillers $(\mathrm{V}=357, P=0.011$ [spring wheat fields: mean $=108,575$ DNA copy numbers of the tri 5 gene, $\mathrm{SD}=165,185$, range $=0$ to 729,407 ; winter wheat fields: mean $=24,121$ DNA copy numbers of the tri 5 gene, $\mathrm{SD}=62,779$, range $=0$ to 285,228$]$ ). Populations of $B$. sorokiniana as expressed by DNA copy numbers of the gpd gene were not different between spring and winter wheat naturally infected fields $(\mathrm{V}=229, P=0.717$ [spring wheat fields: mean = 518 DNA copy numbers of the gpd gene, $\mathrm{SD}=1,663$, range $=0$ to 8,625 ; winter wheat fields: mean $=404$ DNA copy numbers of the gpd gene, $\mathrm{SD}=1,096$, range $=0$ to 6,294$]$ ), while populations of B. sorokiniana in the Bozeman experimental sites (mean $=6,562$ DNA copy numbers of the gpd gene, $\mathrm{SD}=13,492$, range $=0$ to 25,868 ) were different from the $B$. sorokiniana populations quantified for spring wheat $(\mathrm{V}=81, P=<0.001)$ and winter wheat fields (V $=118, P=0.001)$.

Dependency between copy numbers of Fusarium spp. of the FCR complex and B. sorokiniana in individual tillers showed a significant negative correlation for the tillers collected from the coinoculated plots (Spearman rank coefficient: $r=-0.713, P<0.001$ ) and for the tillers showing infection by one or both diseases collected from the naturally infested fields (Spearman rank coefficient: $r=-0.507, P<0.001)$. Infected tillers collected from both spring wheat and winter wheat naturally infested fields had a negative correlation (spring wheat Spearman rank coefficient: $r=$ $-0.480, P=0.011$; winter wheat Spearman rank coefficient: $r=$ $-0.613, P=<0.001)$. The same was observed for co-inoculated tillers collected from the experimental site in Bozeman but the

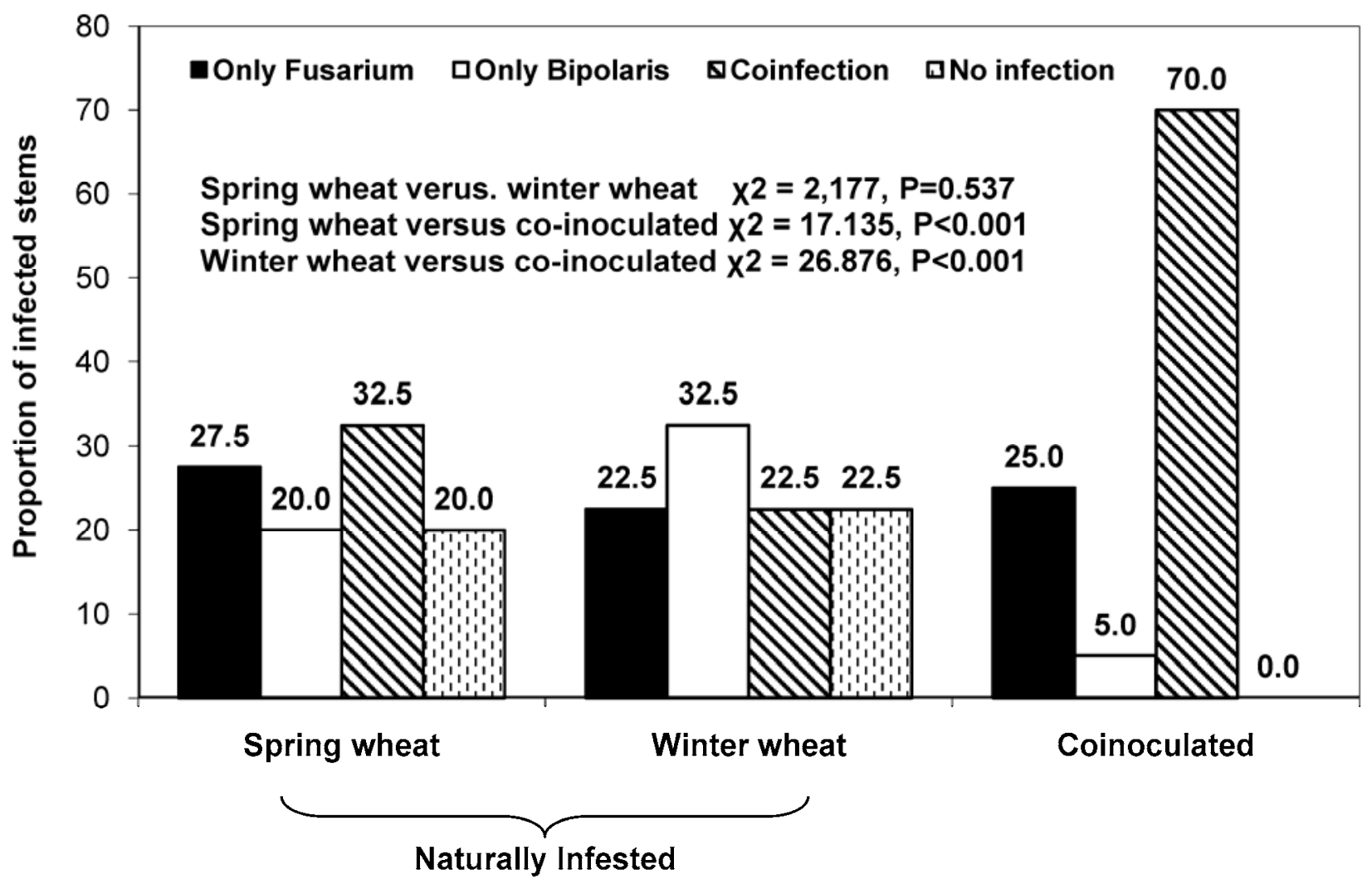

Fig. 4. Proportion of 40 individual lower internodes infected by Fusarium spp. (Fusarium culmorum, F. pseudograminearum, and F. graminearum) or Bipolaris sorokiniana, coinfected with both Fusarium spp. and $B$. sorokiniana, or not infected with either for stems collected from naturally infested spring wheat and winter wheat fields and from the co-inoculated plots, as determined by real-time quantitative polymerase chain reaction. For naturally infested fields, 20 symptomatic tillers each were collected from spring wheat fields in Shonkin, MT in 2008 and Cut Bank, MT in 2009 and winter wheat fields in Carter, MT in 2008 and Malta, MT in 2009. For co-inoculated tillers, 20 symptomatic tillers were collected from plots co-inoculated with high rates (oat inoculum at $3 \mathrm{~g} / \mathrm{m}$ of row) of both $F$. pseudograminearum isolate 2228 and $B$. sorokiniana isolate 2344 at Bozeman MT in 2008 and 2009. Results were combined across year due to similarity of results and compared using a $\chi^{2}$ goodness-of-fit test $(P<0.05)$. 
effect was more noticeable during the 2008 crop season (Spearman rank coefficient: $r=-0.886, P<0.001)$ compared with the 2009 crop season (Spearman rank coefficient: $r=-0.388, P=0.091$ ).

\section{Discussion}

In this research, increasing rates of $F$. pseudograminearum inoculum were associated with increasing populations of $F$. pseudograminearum and a corresponding decrease in B. sorokiniana populations within the lowest internode of wheat stems. Because of the high indigenous populations of $B$. sorokiniana, it was not possible to evaluate the reciprocal association. The practical implication of this implied antagonism between these pathogens may be that developing control for FCR may not result in the yield gains that one might expect because reduction in FCR-related losses brought about by control of FCR would be partially compensated for by increasing losses due to CRR. For example, development of cultivars resistant to FCR may be associated with increasing losses due to CRR or vice versa. From data collected under natural field situations for this project, almost $50 \%$ of the crown rot samples displayed co-infection in which control of the FCR would likely be replaced by an increase in CRR damage. Whether the reciprocal compensating dynamic occurs is an important question that needs to be addressed. Past studies suggest that $B$. sorokiniana may not have a reciprocal effect on $F$. pseudograminearum populations $(36,46)$ and, therefore, suppression of CRR may yield results more directly proportional to this disease's importance in the wheat agroecosystem.

How $F$. pseudograminearum populations suppress $B$. sorokiniana in the lower internode is unknown. Direct antagonism mediated by antibiosis between $B$. sorokiniana and $F$. pseudograminearum mycelium has been not observed under in vitro conditions (38). Nevertheless, Ledingham (21) reported inhibited germination of $B$. sorokiniana spores by the closely related species $F$. culmorum. Other reports have linked the mycotoxin deoxynivalenol (DON) with reduction of gene expression in Trichoderma atroviride (25). However, in preliminary in vitro experiments using filter discs amended with DON (at $100 \mu \mathrm{g} / \mu \mathrm{l}$ ), we could not show reduced growth of $B$. sorokiniana isolate 2234 (data not shown). Within wheat tissue, both Tinline (46) and Scardacci and Webster (36) reported that $F$. culmorum and $F$. graminearum infection, respectively, prevented later B. sorokiniana infections. If this exclusion dynamic dominates these interactions under natural field conditions, one would expect a deficit in co-infections under field conditions. This was not observed in the trials reported here but more study of its potential appears warranted. Another explanation for the dynamics observed would be that resource competition was involved. Inverse dependence between both pathogen populations was observed at harvest in the plot in Bozeman 2008 and for tillers collected from naturally infected and co-inoculated sites, which suggested a competition dynamic between the pathogens for the first internode. This dynamic for both pathogen populations was observed occurring at tiller and plot levels in this Montana study, and has been observed at regional levels by Fernandez and Jefferson (10) in the Canadian Prairies and observed by us in Montana (28). If resource competition is involved, one would expect classic zero-sum dynamics to be involved, with associated prediction of community stability and compensatory population dynamics. These were not tested within these trials but should be examined in the future. High colonization of lower internodes by F. pseudograminearum populations at the heading or milk stage was demonstrated in these studies, whereas $B$. sorokiniana populations were not seen increasing within lower internode until harvest stage. These results are in concordance with the observation of Tinline (46) and Scardacci and Webster (36), who determined that other Fusarium spp. preempt B. sorokiniana infection. This phenomenon could be suggesting a "priority effect", where an early colonist negatively affects the performance of later arrivals through preemption of shared resources $(1,37)$. This phenomenon has been described recently playing a major role in the dynamics of early colonization of pine seedlings by ectomycorrhizal fungi $(18,19)$.

In addition to microbe-microbe interactions, the reduction in the population of $B$. sorokiniana by $F$. pseudograminearum populations could have been affected through indirect antagonistic interactions mediated by the plant, as was suggested for some ectomycorrhizal interactions (18). Several studies have revealed evidence of pathogenesis-related proteins induced by $F$. pseudograminearum and $B$. sorokiniana in wheat plants $(4-6,23,24)$. The reduction of $B$. sorokiniana populations could be caused by elicitation of a resistance response by the fungal populations in the wheat plant, which presumably do not affect $F$. pseudograminearum but are capable of attenuating $B$. sorokiniana colonization of roots, crowns, or culms. Recently, this model was suggested to explain the interaction between Phytophthora medicaginis E.M. Hansen \& D.P. Maxwell and Aphanomyces euteiches Drechsler in alfalfa (49).

The results from individual tiller evaluations showed that the use of pathogen inoculations resulted in greater incidence of infection by $F$. pseudograminearum and $B$. sorokiniana and, therefore, greater incidence of co-infection than that observed in natural settings. This also suggests that the competitive effects witnessed in the field trials are less common under natural field conditions. Differences observed between inoculated trials and naturally coinfested fields provides us with a warning that these studies must examine interaction dynamics in the natural setting in order to place the dynamics into their proper agroecological perspective. From the agronomic point of view, these results showed that a high level of inoculum in field trials would overestimate the incidence and level of antagonism present in naturally infected fields.

During the establishment of the crop, co-inoculations reduced seedling stands more than single inoculations with either pathogen. In addition, an increase in inoculum levels was associated with greater reduction in the emergence for the three trials. These results were in accordance with the results obtained by the classical mixed experiments conducted by Hynes $(9,21)$, who demonstrated that disease expression at seedling stage was considerably enhanced by co-inoculation with $B$. sorokiniana and $F$. culmorum. However, these results were different from the results of Ledingham's (21) field experiments, where combined inoculums of $B$. sorokiniana and $F$. culmorum did not lower seedling emergence as much as the more aggressive of the single pathogen inoculations. Statistical interactions between concentration of inoculum from Fpg2228 and Bs2344 were not observed (data not shown). This situation suggests that the reduction in seedling counts by a combination of inoculum would be associated with the increased inoculum levels represented by the combined inoculums and not due to filling complementary niches. In contrast to seedling stand, yield was only reduced by inoculation with $F$. pseudograminearum in 2008. Inoculation with $B$. sorokiniana did not reduce yield significantly over the noninoculated control, and co-inoculations did not show any additional effect on yield above that seen with individual inoculation with $F$. pseudograminearum. According to these results, Fusarium spp. populations could be considered a more aggressive late-season pathogen and better colonizers of lower internodes than $B$. sorokiniana on wheat. Unfortunately, late-season populations of B. sorokiniana were only marginally increased by inoculations and, therefore, their relative effect on $F$. pseudograminearum populations and other parameters such as yield cannot be ascertained by the results of this study.

This study only examined pathogen population dynamics at the base of the first stem internode, and the competitive relationship elsewhere in the plant was not addressed. Infection by $B$. sorokiniana has long been associated with infections of the subcrown internode and culm bases $(9,36,46)$, and this has been associated with yield losses (22). For this reason, the assessment of rot at the subcrown internode has been commonly used to define CRR damage $(10,12,13,43,44,50-52)$. If $B$. sorokiniana has some adaptation favoring its colonization of subcrown internodes, sampling of the first stem internode could bias the population dynamics observed 
by this study toward F. pseudograminearum. Whether the dynamic between these two pathogens would be reversed if the focus of population studies was on the subcrown internodes is something worthy of further study.

The effect of environmental factors on population dynamics of $F$. pseudograminearum and $B$. sorokiniana was observed by this study. Prevailing environmental conditions accelerated or delayed the progression of $F$. pseudograminearum and $B$. sorokiniana across field trials. This was observed at the Bozeman 2009 site, where inoculation did not result in significant increases in pathogen populations due to uncommonly high summer rainfall and lower temperatures that did not favor disease development. In contrast, warmer and drier conditions observed during summer months for both locations in 2008 favored FCR $(3,31,40)$ and CRR development (50), inoculations were more effective, and, as a result, population dynamics were more easily observed.

In conclusion, the competition dynamics between both $F$. pseudograminearum and $B$. sorokiniana showed that rates of $F$. pseudograminearum inoculum were associated with reduction of $B$. sorokiniana populations in the first internode in the field trials. This may have implications for disease control strategies in the future because control of FCR may lead to replacement by CRR. The reciprocal dynamics are unknown. Populations of $B$. sorokiniana may or may not reduce $F$. pseudograminearum populations because high native populations of $B$. sorokiniana obscured dynamics in these experiments and prevented a conclusion being drawn. Both $F$. pseudograminearum and $B$. sorokiniana populations in the wheat stems increased from heading through harvest, with $F$. pseudograminearum preemptively colonizing lower internodes relative to $B$. sorokiniana. Despite effects on their community dynamics, $F$. pseudograminearum and $B$. sorokiniana did not prevent infection by the other in the first internode of wheat plants. Inoculation significantly increased incidence of infection and co-infection relative to natural settings and may have increased the levels of competition observed relative to natural setting. These trials demonstrated the utility of qPCR technique to examine the population dynamics of multiple pathogens in mixed-plant infections under field conditions and showed the importance of comparing the level of infection developed in inoculated experimental trials with real-world agricultural systems managed by growers. Additional studies are warranted to understand this interplay within different disease systems and how variability within species such as F. pseudograminearum and B. sorokiniana affect their interspecies competition.

\section{Acknowledgments}

This research was supported in part by funds from the Montana Wheat and Barley Committee and the Montana Agricultural Experiment Station. We thank B. Johnston, D. Wichman, and J. Johnston for their support and assistance during the experimental work.

\section{Literature Cited}

1. Alford, R., and Wilbur, H. 1985. Priority effects in experimental pond communities: competition between Bufo and Rana. Ecology 66:1097-1105.

2. Backhouse, D., Abubakar, A., Burgess, L., Dennis, J., Hollaway, G., Wildermuth, G., and Henry, F. 2004. Survey of Fusarium species associated with crown rot of wheat and barley in eastern Australia. Australas. Plant Pathol. 33:255-261.

3. Cook, R. J. 1981. Fusarium diseases of wheat and other small grains in North America. Pages 39-52 in: Fusarium: Diseases, Biology, and Taxonomy. P. E. Nelson, T. A. Toussoun, and R. J. Cook, eds. Pennsylvania State University Press, University Park.

4. Desmond, O. J., Edgar, C. I., Manners, J. M., Maclean, D. J., Schenk, P. M., and Kazan, K. 2006. Methyl jasmonate induced gene expression in wheat delays symptom development by the crown rot pathogen Fusarium pseudograminearum. Physiol. Mol. Plant Pathol. 67:171-179.

5. Desmond, O. J., Manners, J. M., Schenk, P. M., Maclean, D. J., and Kazan, K. 2008. Gene expression analysis of the wheat response to infection by Fusarium pseudograminearum. Physiol. Mol. Plant Pathol. 73:40-47.

6. Desmond, O. J., Manners, J. M., Stephens, A. E., Maclean, D. J., Schenk, P. M., Gardiner, D. M., Munn, A. L., and Kazan, K. 2008. The Fusarium mycotoxin deoxynivalenol elicits hydrogen peroxide production, programmed cell death and defense responses in wheat. Mol. Plant Pathol. 9:435-445.

7. Diehl, J. A., Tinline, R. D., Kochhann, R. A., Shipton, P. J., and Rovira, A. D. 1982. The effect of fallow periods on common root rot of wheat in Rio Grande do Sul, Brazil. Phytopathology 72:1297-1301.
8. Dyer, A. T., Johnston, R. H., Hogg, A. C., and Johnston, J. A. 2009. Comparison of pathogenicity of the Fusarium crown rot complex (F. culmorum, $F$. pseudograminearum and $F$. graminearum) on hard red spring and durum wheat. Eur. J. Plant Pathol. 125:387-395.

9. Fedel-Moen R., and Harris, J. R. 1987. Stratified distribution of Fusarium and Bipolaris on wheat and barley with dryland root rot in South Australia. Plant Pathol. 36:447-454.

10. Fernandez, M. R., and Jefferson, P. G. 2004. Fungal populations in roots and crowns of common and durum wheat in Saskatchewan. Can. J. Plant Pathol. 26:325-334.

11. Fernandez, J. A., Wofford, D. S., and Horton, J. L. 1985. Augmentation of wheat common root rot by Fusarium acuminatum. Mycopathologia 90:177179.

12. Fernandez, M. R., Basnyat, P., and Zentner, R. P. 2007. Response of common root rot in wheat to crop management in eastern Saskatchewan. Can. J. Plant Sci. 87:953-963.

13. Fernandez, M. R., Zentner, R. P., DePauw, R. M., Gehl, D., and Stevenson F. C. 2007. Impacts of crop production factors on common root rot of barley in Eastern Saskatchewan. Crop Sci. 47:1585-1595.

14. Gonzalez, M. S., and Trevathan, L. E. 2000. Identity and pathogenicity of fungi associated with root and crown rot of soft red winter wheat grown on the upper coastal plain land resource area of Mississippi. J. Phytopathol 148:77-85.

15. Hogg, A. C., Johnston, R. H., and Dyer, A. T. 2007. Applying real-time quantitative PCR to Fusarium crown rot of wheat. Plant Dis. 91:1021-1028.

16. Hogg, A. C., Johnston, R. H., Johnston, J. A., Klouser, L., Kephart, K. D. and Dyer, A. T. 2010. Monitoring Fusarium crown rot populations in spring wheat residues using quantitative real-time polymerase chain reaction. Phytopathology 100:49-57.

17. Kennedy, P., Bergemann, S., Hortal, S., and Bruns, T. 2007. Determining the outcome of field-based competition between two Rhizopogon species using real-time PCR. Mol. Ecol. 16:881-890.

18. Kennedy, P., and Bruns, T. 2005. Priority effects determine the outcome of ectomycorrhizal competition between two Rhizopogon species colonizing Pinus muricata seedlings. New Phytol. 166:631-638.

19. Kennedy, P. G., Peay, K. G., and Bruns, T. D. 2009. Root tip competition among ectomycorrhizal fungi: are priority effects a rule or an exception? Ecology 90:2098-2107.

20. Kumar, J., Schäfer, P., Hückelhoven, R., Langen, G., Baltruschat, H., Stein, E., Nagarajan, S., and Kogel, K. H. 2002. Bipolaris sorokiniana, a cereal pathogen of global concern: cytological and molecular approaches towards better control. Mol. Plant Pathol. 3:185-195.

21. Ledingham, R. J. 1942. Observation on antagonism in inoculation tests of wheat with Helminthosporium sativus P.K. \& B., and Fusarium culmorum (W. G. SM.) Sacc. Sci. Agric. 22:688-697.

22. Ledingham, R J., Atkinson, T. G., Horricks, J. S., Mills, J. T., Piening, L. J. and Tinline, R. D. 1973. Wheat losses due to common root rot in the prairie provinces of Canada 1969-71. Can. Plant Dis. Surv. 53:113-122.

23. Li, X., Zhang, J. B., Song, B., Li, H. P., Xu, H. Q., Qu, B., Dang, F. J., and Liao, Y. C. 2010. Resistance to Fusarium head blight and seedling blight in wheat is associated with activation of a cytochrome P450 gene. Phytopathology 100:183-191.

24. Liljeroth, E., Santén, K., and Bryngelsson, T. 2001. PR Protein accumulation in seminal roots of barley and wheat in response to fungal infection the importance of cortex senescence. J. Phytopathol. 149:447-456.

25. Lutz, M. P., Feichtinger, G., Défago, G., and Duffy, B. 2003. Mycotoxigenic Fusarium and deoxynivalenol production repress chitinase gene expression in the biocontrol agent Trichoderma atroviride P1. Appl. Environ. Microb. 69:3077-3084.

26. Mathieson J. T., Rush, C. M., Bordovsky, D., Clark, L. E., and Jones, O. R. 1990. Effects of tillage on common root rot of wheat in Texas. Plant Dis. 74:1006-1008.

27. Mathre, D. E., and Johnston, R. H. 1975. Cephalosporium stripe of winter wheat: procedures for determining host response. Crop Sci. 15:591-594.

28. Moya-Elizondo, E. A., Rew, L. J., Jacobsen, B. J., Hogg, A. C., and Dyer, A. T. 2011. Distribution and prevalence of Fusarium crown rot and common root rot pathogens of wheat in Montana.Plant Dis. 95:1099-1108.

29. Painter, J. E., and Lambert, K. N. 2003. Meloidogyne javanica chorismate mutase transcript expression profile using real-time quantitative RT-PCR. J. Nematol. 35:82-87.

30. Paulitz, T. C., Schroeder, K. L., and Schillinger, W. F. 2010. Soilborne pathogens of cereals in an irrigated cropping system: effects of tillage, residue management, and crop rotation. Plant Dis. 94:61-68.

31. Paulitz, T. C., Smiley, R. W., and Cook, R. J. 2002. Insight into the prevalence and management of soilborne cereal pathogens under direct seeding in the Pacific Northwest, U.S.A. Can. J. Plant Pathol. 24:416-428.

32. Pereyra, S. A., and Dill-Macky, R. 2004. Survival and inoculum production of Gibberella zeae in wheat residue. Plant Dis. 88:724-730.

33. Pettitt, T., Xu, X., and Parry, D. 2003. Association of Fusarium species in the wheat stem rot complex. Eur. J. Plant Pathol. 109:769-774.

34. Salas, B., and Stack, R. W. 1988. Effect of cultural practices on common root rot of spring wheat. (Abstr.) Phytopathology 78:1598.

35. Saremi, H., Ammarellou, A., and Jafary, H. 2007. Incidence of crown rot disease of wheat caused by Fusarium pseudograminearum as a new soil 
born fungal species in northwest Iran. Pak. J. Biol. Sci. 10:3606-3612.

36. Scardaci, S. C., and Webster, R. K. 1981. Antagonism between the cereal root rot pathogens Fusarium graminearum and Bipolaris sorokiniana. Plant Dis. 65:965-967.

37. Shorrocks, B., and Bingley, M. 1994. Priority effects and species coexistence: experiments with fungal-breeding Drosophila. J. Anim. Ecol. 63:799-806.

38. Singh, D. V., Backhouse, D., and Kristiansen, P. 2009. Interactions of temperature and water potential in displacement of Fusarium pseudograminearum from cereal residues by fungal antagonists. Biol. Control 48:188-195.

39. Sitton, J. W., and Cook, R. J. 1981. Comparative morphology and survival of chlamydospores of Fusarium roseum 'Culmorum' and 'Graminearum'. Phytopathology 71:85-90.

40. Smiley, R. W. 2009. Water and temperature parameters associated with winter wheat diseases caused by soilborne pathogens. Plant Dis. 93:73-80.

41. Smiley, R. W., Gourlie, J. A., Easley, S. A., Patterson, L. M., and Whittaker, R. G. 2005. Crop damage estimates for crown rot of wheat and barley in the Pacific Northwest. Plant Dis. 89:595-604.

42. Smiley, R. W., and Patterson, L. M. 1996. Pathogenic fungi associated with Fusarium foot rot of winter wheat in the semiarid Pacific Northwest. Plant Dis. 80:944-949.

43. Specht, L. P., and Rush, C. M. 1988. Fungi associated with root and foot rot of winter wheat and populations of Cochliobolus sativus in the Texas Panhandle. Plant Dis. 72:959-963.

44. Strausbaugh, C. A., Bradley, C. A., Koehn, A. C., and Forster, R. L. 2004. Survey of root diseases of wheat and barley in southeastern Idaho. Can. J. Plant Pathol. 26:167-176.
45. Strausbaugh, C. A., Overturf, K., and Koehn, A. C. 2005. Pathogenicity and real-time PCR detection of Fusarium spp. in wheat and barley roots. Can. J. Plant Pathol. 27:430-438.

46. Tinline, R. D. 1977. Multiple infections of subcrown internodes of wheat (Triticum aestivum) by common root rot fungi. Can. J. Bot. 55:30-34.

47. Tinline, R. D., and Spurr, D. T. 1991. Agronomic practices and common root rot in spring wheat: effect of tillage on disease and inoculum density of Cochliobolus sativus in soil. Can. J. Plant Pathol. 13:258-266.

48. Tunali, B., Nicol, J. M., Hodson, D., Uçun, Z., Büyük, O., Erdurmus, D., Hekimhan, H., Aktaş, H., Akbudak, M. A., and Bağci, S. A. 2008. Root and crown rot fungi associated with spring, facultative, and winter wheat in Turkey. Plant Dis. 92:1299-1306.

49. Vandemark, G. J., Ariss, J. J., and Hughes, T. J. 2010. Real-time PCR suggests that Aphanomyces euteiches is associated with reduced amounts of Phytophthora medicaginis in alfalfa that is co-inoculated with both pathogens. J. Phytopathol. 158:117-124.

50. Wildermuth, G. B. 1986. Geographic distribution of common root rot and Bipolaris sorokiniana in Queensland wheat soils. Aust. J. Exp. Agric. 26:601-606

51. Wildermuth, G. B., Thomas, G. A., Radford, B. J., McNamara, R. B., and Kelly, A. 1997. Crown rot and common root rot in wheat grown under different tillage and stubble treatments in southern Queensland, Australia. Soil Till. Res. 44:211-224.

52. Windels, C. E., and Holen, C. 1989. Association of Bipolaris sorokiniana, Fusarium graminearum group 2, and F. culmorum on spring wheat differing in severity of common root rot. Plant Dis. 73:953-956. 